\title{
Pengaruh Penerapan Prinsip-Prinsip Good Governance Terhadap Kinerja Pada Rumah Sakit Di Kota Denpasar
}

\author{
Ida Ayu Arina Mahadewi ${ }^{1}$ \\ I G. A. M. Asri Dwija Putri \\ ${ }^{1,2}$ Fakultas Ekonomi dan Bisnis Universitas Udayana (Unud), Bali, Indonesia \\ e-mail: arinamahadewi@gmail.com
}

\begin{abstract}
ABSTRAK
Penelitian ini bertujuan untuk mengetahui pengaruh prinsip-prinsip Good Corporate Governance yaitu: transparansi, akuntabilitas, responsibilitas, independensi, serta kewajaran terhadap Kinerja pada Rumah Sakit di Kota Denpasar. Jumlah sampel atau populasi yang digunakan dalam penelitian ini sebanyak 20 rumah sakit dengan penentuan sampel menggunakan metode purposive sampling, jumlah responden keseluruhan sebanyak 120 responden. Teknik analisis data yang digunakan adalah analisis regresi linier berganda. Berdasarkan hasil penelitian ini menunjukkan bahwa transparansi, akuntabilitas, responsibilitas, independensi, serta kewajaran berpengaruh positif terhadap Kinerja pada Rumah Sakit di Kota Denpasar. Hasil penelitian ini diharapkan mampu memberikan informasi bagi pihak-pihak yang terkait dalam mengukur kinerja pada Rumah Sakit di Kota Denpasar dengan menerapkan prinsip-prinsip Good Corporate Governance dalam mengambil keputusan dan menentukan kebijakan di masa yang akan datang sehingga nantinya dapat meningkatkan kinerja organisasi.
\end{abstract}

Kata kunci: Transparansi, akuntabilitas, responsibilitas, independensi, kewajaran, kinerja

\begin{abstract}
This study aims to determine the effect of the principles of Good Corporate Governance, namely: transparency, accountability, responsibility, independence, and fairness to the performance of hospitals in the city of Denpasar. The number of samples or population used in this study were 20 hospitals with the determination of samples using purposive sampling method, the total number of respondents was 120 respondents. The data analysis technique used is multiple linear regression analysis. Based on the results of this study indicate that transparency, accountability, responsibility, independence, and fairness positively influence the performance of hospitals in the city of Denpasar. The results of this study are expected to be able to provide information for parties involved in measuring performance in hospitals in the city of Denpasar by applying the principles of Good Corporate Governance in making decisions and determining policies in the future so that later can improve organizational performance.
\end{abstract}

Keywords: Transparency, accountability, responsibility, independence, fairness, performance

\section{PENDAHULUAN}

Rumah sakit yang merupakan salah satu dari sarana kesehatan, merupakan rujukan pelayanan kesehatan dengan fungsi utama menyelenggarakan upaya kesehatan yang bersifat penyembuhan dan pemulihan bagi pasien (Depkes RI, 
Ida Ayu Arina Mahadewi dan I G A. M. Asri Dwija Putri. Pengaruh ...

2004). Sesuai dengan Keputusan Menteri Kesehatan Republik Indonesia No.1204/Menkes/SK/X/2004 tentang Persyaratan Kesehatan Lingkungan Rumah Sakit, dinyatakan bahwa: "Rumah sakit merupakan sarana pelayanan kesehatan, tempat berkumpulnya orang sakit maupun orang sehat, atau dapat menjadi tempat penularan penyakit serta memungkinkan terjadinya pencemaran lingkungan dan gangguan kesehatan”.

Menurut Undang-Undang RI Nomor 44 tahun 2009 dan Peraturan Menteri Kesehatan Republik Indonesia No. 340/MENKES/PER/III/2010 tentang rumah sakit, yang dimaksud rumah sakit adalah "Institusi yang memberikan pelayanan kesehatan yang bermutu dan terjangkau kepada masyarakat dalam menyelenggarakan pelayanan kesehatan perorangan secara paripurna yang menyediakan pelayanan rawat inap, rawat jalan dan gawat darurat”.

Berdasarkan UU tersebut, rumah sakit mempunyai fungsi sebagai berikut: Penyelenggaraan pelayanan pengobatan dan pemulihan kesehatan sesuai dengan standar pelayanan rumah sakit. Pemeliharaan dan peningkatan kesehatan perorangan melalui pelayanan kesehatan yang paripurna. Penyelenggaraan pendidikan dan pelatihan sumber daya manusia dalam rangka peningkatan kemampuan dalam pemberian pelayanan kesehatan. Penyelenggaraan penelitian dan pengembangan serta penapisan teknologi bidang kesehatan dalam rangka peningkatan pelayanan kesehatan dengan memperhatikan etika ilmu pengetahuan bidang kesehatan.

Di Indonesia, rumah sakit merupakan rujukan pelayanan kesehatan untuk pusat kesehatan masyarakat (Puskesmas), terutama upaya penyembuhan dan 
pemulihan, sebab rumah sakit mempunyai fungsi utama menyelenggarakan upaya kesehatan yang bersifat penyembuhan dan pemulihan bagi penderita, yang berarti bahwa pelayanan rumah sakit untuk penderita rawat jalan dan rawat inap hanya bersifat spesialistik atau subspesialistik, sedang pelayanan yang bersifat non spesialistik atau pelayanan dasar harus dilakukan di Puskesmas.

Hal tersebut diperjelas dalam keputusan menteri Kesehatan Republik Indonesia Nomor : 983/Menkes/SK/XI/1992, tentang pedoman organisasi Rumah Sakit Umum yang menyebutkan bahwa tugas rumah sakit mengutamakan upaya penyembuhan dan pemulihan yang dilaksanakan secara serasi dan terpadu dengan upaya peningkatan dan pencegahan serta melaksanakan upaya rujukan (Depkes RI, 2004).

Dengan latar belakang perkembangan tersebut, maka pada bulan November 2004, Pemerintah dengan Keputusan Menko Bidang Perekonomian Nomor: KEP/49/M.EKON-/11/2004 telah menyetujui pembentukan Komite Nasional Kebijakan Governance (KNKG) yang terdiri dari Sub-Komite Publik dan Sub-Komite Korporasi. Dengan telah dibentuknya KNKG, maka Keputusan Menko Ekuin Nomor: KEP.31/M.EKUIN/06/2000 yang juga mencabut keputusan No.KEP.10/M.EKUIN/08/1999 tentang pembentukan KNKCG dinyatakan tidak berlaku lagi.

Isu mengenai GCG di Indonesia mulai mengemuka saat Indonesia menderita krisis berkepanjangan sejak tahun 1998. Maka sejak saat itu, pemerintah dan investor mulai memberikan perhatian pada penerapan GCG pada perusahaan-perusahaan di Indonesia (Wikrami \& Asika, 2016). Di Indonesia 
Ida Ayu Arina Mahadewi dan I G A. M. Asri Dwija Putri. Pengaruh ...

seluruh perusahaan harus menerapkan prinsip-prinsip good corporate governance (Setyawan \& Putri, 2013).

Pelaksanaan Good Corporate Governance sangat dibutuhkan untuk menjaga kelangsungan hidup sebuah perusahaan. Menurut KNKG dalam Pedoman Umum Good Corporate Governance Indonesia (2006), pelaksanaan ini didasarkan atas lima prinsip: transparency (transparansi), accountability (akuntabilitas), responsibility (responsibilitas), independency (independensi), serta fairness (kewajaran). Namun, tidak semua perusahaan menjalankan prinsipprinsip Good Corporate Governance dengan baik.

Berdasarkan latar belakang masalah diatas telah mendorong penulis untuk melakukan penelitian. Penelitian ini mengenai penerapan prinsip Good Corporate Governance dilakukan dengan tujuan, untuk meneliti keterkaitan prinsip Corporate Governance yang terdiri dari trasnparansi, akuntabilitas, responsibilitas, independensi, dan kewajaran yang diterapkan pada Rumah Sakit di Kota Denpasar dengan kinerja yang bersangkutan.

Teori keagenan (agency theory) merupakan landasan hal dasar yang digunakan untuk memahami dan menjelaskan konsep Corporate Governance. Teori agen ini dikembangkan oleh Michael Johnson, yang memandang bahwa manajemen perusahaan (agents) akan bertindak dengan penuh kesadaran bagi kepentingannya sendiri, bukan sebagai pihak yang bijaksana serta adil terhadap pemegang saham. Semakin besar perusahaan maka akan terjadi pemisahaan antara pemilik dan pengendali perusahaan (I. G. A. M. A. D. Putri, Ulupui, \& Wirawati, 2017). 
Teori agen dipandang lebih luas karena teori ini dianggap lebih mencerminkan kenyataan yang ada. Berbagai pemikiran mengenai corporate governance berkembang dengan bertumpu pada teori agen dimana pengelolaan dilakukan dengan penuh kepatuhan kepada berbagai peraturan dan ketentuan yang berlaku (Wirawan \& Putri, 2018). Dengan kata lain. corporate governance diharapkan dapat berfungsi untuk menekan atau menurunkan konflik keagenan. (I. A. D. Putri, 2012).

Menurut Anthony \& Govindrajan (2005:269) mengatakan bahwa salah satu elemen kunci dari teori agensi adalah hubungan atau kontrak antara principal dan agent memiliki prefensi atau tujuan yang beda. Teori agensi memiliki asumsi bahwa tiap-tiap individu semata-mata termotivasi oleh kepentingan dirinya sendiri sehingga menimbulkan konflik kepentingan antara principal dan agent.

Jensen \& Meckling (1976) menjelaskan jika keduanya hubungan kelompok keagenan merupakan suatu kontrak dimana satu atau lebih orang (prinsipal) memerintah orang lain (agent) untuk melakukan suatu jasa atas nama prinsipal serta memberi wewenang kepada agen membuat keputusan yang terbaik bagi prinsipal.

Hubungan asimetri antara pemilik dan pengelola yang diakibatkan oleh teori agensi, dapat dihindari dan diminimalisir dengan membuat suatu kerangka atau konsep Good Corporate Governance yang akan menjadikan perusahaan menjadi lebih sehat sebagai tujuan utama (Wirawan \& Putri, 2018). Teori keagenan akan muncul ketika terjadi sebuah kontrak antara manajer (agent) dengan pemilik (principal). 
Dimana seorang manajer akan lebih mengetahui keadaan perusahaannya dibandingkan dengan pemilik. Manajer berkewajiban memberikan informasi kepada pemilik akan tetapi informasi yang disampaikan tidak sesuai dengan keadaan sebenarnya dari perusahaan. Teori keagenan menjelaskan kedua pihak ingin memperbanyak utilitasnya maka dari itu muncul konflik keagenan. Untuk mengatasi masalah tersebut perlu memberikan perhatian pada lemahnya penerapan tata kelola perusahaan yang disebut dengan istilah good corporate governance (GCG) (Peni et al., 2012)

Teori Penatalayanan (Stewardship Theory) adalah teori yang menggambarkan situasi kondisi dimana para manajer tidaklah termotivasi oleh tujuan individu tetapi lebih ditunjukan pada sasaran hasil utama mereka untuk kepentingan organisasi, sehingga teori ini memiliki dasar psikologi dan sosiologi yang telah dirancang dimana para eksekutif sebagai steward tidak akan meninggalkan organisasinya sebab steward berusaha mencapai sasaran organisasinya. Teori ini di desain bagi para peneliti untuk menguji situasi dimana para eksekutif dalam perusahaan sebagai pelayan dapat termotivasi untuk bertindak dengan cara terbaik pada prinsipalnya (Donaldson \& Davis, 1991).

Menurut Anton (2010) steward melindungi dan memaksimumkan shareholder melalui kinerja perusahaan, oleh karena itu fungsi utilitas steward dimaksimalkan. Steward yang dengan sukses dapat meningkatkan kinerja perusahaan akan mampu memuaskan sebagian besar organisasi yang lain, sebab sebagian besar shareholder memiliki kepentingan yang telah dilayani dengan baik lewat peningkatan kemakmuran yang diraih organisasi. Teori stewardship dalam 
penelitian ini dipertimbangkan dapat menjelaskan bahwa prinsip-prinsip good corporate governance yang terdapat dalam perusahaan akan memaksimalkan kinerjanya agar tujuan perusahaan dapat tercapai.

Good corporate governance merupakan suatu sistem, dimana yang mengoperasikannya adalah manusia, adapun kesuksesan penerapannya sangat bergantung pada integritas dan komitmen. Good corporate governance merupakan prinsip yang universal, sehingga dapat ditemukan pada kultur budaya dimanapun. Hal yang membedakan praktek Good Corporate Governance di suatu negara adalah Good Corporate Governance sebagai sistem, karena harus selalu menyesuaikan dengan sistem hukum, keadaan dan perkembangan kemajuan, serta kultur bangsa itu sendiri ( Putri \& Ulupui, 2017)

Penerapan GCG yang baik pada suatu perusahaan akan memberikan sinyal positif kepada stakeholder, karena stakeholder merasa kepentingannya akan lebih terlindungi (Permatasari \& Gayatri, 2016). Secara umum GCG adalah hubungan antara semua pihak yang berkepentingan dalam bisnis yang telah diatur dan terorganisir (Mahaendrayasa \& Putri, 2017). Sehubungan dengan pentingnya pelaksanaan GCG, Pemerintah juga semakin menyadari perlunya penerapan good governance di sektor publik, mengingat pelaksanaan GCG oleh dunia usaha tidak mungkin dapat diwujudkan tanpa adanya good public governance dan partisipasi masyarakat.

Transparansi (Transparency) merupakan penyampaian informasi dan keterbukaan dalam proses pengambilan keputusan. Prinsip transparansi pada perusahaan ini dilihat dari aspek penyampaian visi, misi, kebijakan perusahaan, 
serta informasi yang dibagikan karyawan dan pemerintah. Visi dan misi perusahaan sudah diketahui seluruh karyawan dan dilaksanakan dengan baik. Kemudian mengenai informasi laporan keuangan dalam perusahaan hanya boleh diketahui oleh pihak-pihak tertentu seperti komisaris, direktur, dan bagian keuangan. Kebijakan pada perusahaan sudah disampaikan secara lisan dan tertulis sehingga tidak ada karyawan yang tidak mengetahui kebijakan perusahaan dan setiap satu bulan sekali perusahaan mengadakan rapat besar yang dimana untuk menyampaikan kebijakan-kebijakan tersebut. Perusahaan juga melakukan evaluasi setiap hari terhadap kebijakan yang sudah dibuat. Mengenai website pada perusahaan, narasumber mengatakan bahwa perusahaan memiliki website yang dimana berisi tentang informasi mengenai fasilitas-fasilitas yang diberikan rumah sakit serta informasi tentang dokter-dokter yang melayani disana sebagai bentuk transparansi terhadap pasien. Kemudian terkait dengan transparansi ke pemerintah Rumah Sakit sebulan sekali melaporkan pajak dan membayar Surat Pemberitahuan Tahuan setiap setahun sekali. Perusahaan juga sudah transparan terhadap karyawan terutama pada masalah gaji, dimana perusahaan memberikan slip gaji pada karyawan, kemudian memberikan tambahan poin jasa pelayanan pada karyawan.

$\mathrm{H}_{1}$ : Transparansi berpengaruh positif terhadap Kinerja pada Rumah Sakit di Kota Denpasar

Akuntabilitas (Accountability) yaitu mengenai rincian tugas dan tanggung jawab masing-masing organ serta kinerja dalam perusahaan. Pada prinsip accountability, pelaksanaan tugas dan tanggung jawab masing-masing organ dalam perusahaan diakui narasumber sudah berjalan dengan baik karena sudah 
berjalan sebagaimana mestinya seperti yang sudah dirancangkan. Penyampaian dan penjelasan mengenai tanggungjawab masing-masing di sampaikan secara tertulis atau lisan. Mengenai alur pertanggungjawaban pun sudah sangat jelas. Setiap staff atau unit wajib melaporkan setiap kegiatannya kepada kepala unit masing-masing. Kemudian dalam kegiatan operasionalnya rumah sakit memiliki shift-shift kerja yang terbagi menjadi tiga shift yaitu shift pagi, shift siang, dan shift malam. Mengenai evaluasi kinerja pada karyawan, perusahaan biasanya melakukannya tiga bulan, setahun sekali hingga dua tahun sekali. Rumah Sakit telah menerapkan sistem reward dan puni-shment. Perusahaan menerapkan sistem punishment dengan memberikan SP (surat peringatan) yang dimana ada tingkatannya yaitu SP 1, SP 2, dan SP 3. SP 1 yaitu pengurangan poin jasa pelayanan sebesar 20 poin, SP 2 pemotongan poin jasa pelayanan lebih besar yaitu 30 poin, kemudian SP 3 adalah surat pemecatan. Sementara sistem reward perusahaan memberikan tambahan poin jasa pelayanan.

$\mathrm{H}_{2}$ : Akuntanbilitas berpengaruh positif terhadap Kinerja pada Rumah Sakit di Kota Denpasar

Responsibilitas (Responsibility) merupakan bentuk kepatuhan perusahaan terhadap hukum dan perundang-undangan serta tanggung jawab sosial perusahaan terhadap kepedulian masyarakat dan lingkungan disekitar. Seluruh karyawan Rumah Sakit sudah menaati peraturan rumah sakit yang sudah ada, namun menurut ketiga narasumber terkadang masih ada juga yang melanggarnya. Kemudian terkait dengan upah minimum, dua dari tiga narasumber mengatakan ada posisi tertentu yang sesuai Upah Minimum Kabupaten. Sementara satu narasumber mengatakan sudah sesuai dengan Upah Minimum Kabupaten. Rumah 
Ida Ayu Arina Mahadewi dan I G A. M. Asri Dwija Putri. Pengaruh ...

Sakit juga sudah memberikan asuransi keseluruh karyawannya yaitu BPJS kesehatan dan BPJS ketenagakerjaan. Kemudian perusahaan juga sudah patuh terhadap undang-undang konsumen sesuai dangan aturan kementerian kesehatan. Perusahaan juga sudah melakukan limbah, tetapi satu dari tiga narasumber mengatakan begitu sulit untuk mencapai kriteria yang ditentukan pemerintah, maka dari itu perusahaan bekerja sama dengan instituisi legal untuk melakukan pengelolahan limbah. Terkait corporate social responsibility terhadap masyarakat, Rumah Sakit setiap tahunnya mengadakan bakti sosial, seperti memberikan pelayanan secara gratis kepada masyarakat yang tidak mampu. Sedangkan untuk karyawan, perusahaan mengadakan outbound bersama pada saat ulang tahun perusahaan, hal tersebut menurut narasumber menjadi kegiatan rutin tiap tahun. Menyangkut pemberian cuti kepada karyawan, perusahaan memberikan cuti sebanyak dua belas kali dalam setahun, itu berlaku bagi karyawan yang sudah bekerja minimal setahun.

$\mathrm{H}_{3}$ : Responsibilitas berpengaruh positif terhadap Kinerja pada Rumah Sakit di Kota Denpasar

Independensi (Independency) yaitu Perusahaan harus dikelola secara independen sehingga masing-masing organ perusahaan tidak saling mendominasi dan tidak dapat diintervensi oleh pihak lain. Rumah Sakit sejauh ini mengelola perusahaan secara profesional, hal ini diakui narasumber bila terjadi konflik dalam perusahaan maka seluruh pihak ikut mencari solusinya dan hal tersebut tidak menjadi halangan bagi para petinggi untuk membuat suatu keputusan. Kemudian masih ada karyawan yang bekerja yang tidak sesuai dengan jobdesknya hal tersebut diakui oleh narasumber. Rumah Sakit tidak menyertakan keterlibatan 
keluarga dari pemilik perusahaan untuk membuat suatu keputusan. Rumah Sakit memiliki konsultan pajak untuk mengurusi perpajakan perusahaan. Menurut dua dari tiga narasumber, perusahaan menggunakan jasa konsultan pajak tersebut karena tidak adanya yang sumber daya manusia yang mengerjakan bagian perpajakan perusahaan. Kemudian untuk setiap tahunnya perusahaan melakukan RUPS.

$\mathrm{H}_{4}$ : Independensi berpengaruh positif terhadap Kinerja pada Rumah Sakit di Kota Denpasar

Kewajaran (Fairness) yaitu Perusahaan harus senantiasa memperhatikan kepentingan pemegang saham mayoritas atau minoritas, konsumen serta karyawan berdasarkan asas kewajaran dan kesetaraan. Rumah sakit memberikan kesempatan bagi seluruh stakeholder untuk memberkan saran dan pendapatnya untuk memajukan perusahaan. Kemudian perusahaan juga memperlakukan seluruh karyawan secara adil tidak memandang adanya perbedaan. Perusahaan juga menyediakan customer service untuk melayani komplain dari pasien dan pada hari itu juga komplain tersebut harus segera di tindak lanjuti. Terkait sistem perekrutan, Rumah Sakit biasanya membuka lowongan melalui website atau melalui media sosial, namun menurut narasumber ada yang memasukan surat lamarannya meskipun perusahaan tidak membuka lowongan. Kemudian terkait perlakuan perusahan terhadap karyawannya yang melakukan kesalahan, biasanya perusa-haan melakukan pembinaan dan di bimbing agar tidak mengulangi kesalahan kembali.

$\mathrm{H}_{5}$ : Kewajaran berpengaruh positif terhadap Kinerja pada Rumah Sakit di Kota Denpasar 
Ida Ayu Arina Mahadewi dan I G A. M. Asri Dwija Putri. Pengaruh ...

\section{METODE PENELITIAN}

Penelitian ini dilakukan pada Rumah Sakit yang berada di Wilayah Kota Denpasar, dengan diperoleh data daftar Rumah Sakit yang terdapat di Dinas Kesehatan Provinsi Bali untuk mendapatkan informasi yang diperlukan tentang Rumah Sakit di Wilayah Kota Denpasar. Variabel dependen dalam penelitian ini adalah kinerja berbasis balanced scorecard (Y). Variabel bebas dalam penelitian ini adalah prinsip-prinsip good corporate governance yang terdiri dari 5 (lima) variabel yaitu transparansi $\left(\mathrm{X}_{1}\right)$, akuntabilitas $\left(\mathrm{X}_{2}\right)$, responsibilitas $\left(\mathrm{X}_{3}\right)$, independensi $\left(\mathrm{X}_{4}\right)$, dan kewajaran $\left(\mathrm{X}_{5}\right)$.

Populasi dalam penelitian ini adalah Rumah Sakit di Wilayah Kota Denpasar yang berjumlah 20 Rumah Sakit, maka dari itu populasi dalam penelitian ini sejumlah 20 Rumah Sakit yang ditampilkan dalam Tabel 1 berikut:

Tabel 1.

Daftar Rumah Sakit (RS) di Kota Denpasar

\begin{tabular}{llrl}
\hline No. & \multicolumn{1}{c}{ Nama Rumah Sakit (RS) } & Tingkat & \multicolumn{1}{c}{ Keterangan } \\
\hline 1 & RSUP Sanglah & (A) & Negeri - Jl. Diponegoro \\
2 & RSUD Wangaya & (B) & Negeri - Jl. Kartini No.133 \\
3 & RS Angkatan Darat Udayana & (C) & Negeri - Jl. PB Sudirman No.1 \\
4 & RS Bhayangkara & (C) & Negeri - Jl. Trijata No.32 \\
5 & RS Mata Bali Mandara & (A) & Negeri - Jl. Angsoka No.10 \\
6 & RSUD Bali Mandara Provinsi Bali & (B) & Negeri - Jl. By Pass Ngurah Rai No. 548 \\
7 & RSIA Puri Bunda & (C) & Swasta - Jl.Gatot Subroto VI No.19 \\
8 & RS Puri Raharja & (C) & Swasta - Jl. W.R. Supratman No.14-19 \\
9 & RS Surya Husadha Ubung & (C) & Swasta - Jl. Cokroaminoto No.356 \\
10 & RSIA Pucuk Permata Hati & (C) & Swasta - Jl. Teuku Umar Barat No.71XX \\
11 & RSU Manuaba & (C) & Swasta - Jl. Cokroaminoto No.28 \\
12 & RS Prima Medika & (C) & Swasta - Jl. Pulau Serangan No. 9X \\
13 & RS Bhakti Rahayu & (D) & Swasta - Jl. Gatot Subroto II No.11 \\
14 & RSU Surya Husadha & (C) & Swasta - Jl. Pulau Serangan No.7 \\
15 & RS Bali Royal & (C) & Swasta - Jl. Letda Tantular No.6 \\
16 & RS Bali Med & (C) & Swasta - Jl. Mahendradatta No.57X \\
17 & RS Dharma Yadnya & (C) & Swasta - Jl. W.R. Supratman No.256 \\
18 & RS Kasih Ibu & (C) & Swasta - Jl. Teuku Umar No.120 \\
19 & RS Khusus Gigi dan Mulut Unmas & (B) & Swasta - Jl. Kamboja No.11A \\
20 & RSIA Harapan Bunda & (C) & Swasta - Jl. Tukad Unda No.1 \\
\hline Sumber: Dinas Kesehatan Provinsi Bali, 2018 & &
\end{tabular}


Teknik analisis data yang digunakan dalam penelitian ini seecara statistik dapat diukur dari nilai koefisien determinasi $\mathrm{R}^{2}$, uji statistik $\mathrm{F}$, dan uji statistik t. Pengujian hipotesis pada penelitian ini menggunakan Alat analisis data yang digunakan adalah statistik inference yang bertujuan untuk menguji hipotesis dengan menggunakan regresi linear berganda melalui komputer program SPSS dengan rumus sebagai berikut:

$$
\mathrm{Y}=\mathrm{a}+\beta_{1} \mathrm{X}_{1}+\beta_{2} \mathrm{X}_{2}+\beta_{3} \mathrm{X}_{3}+\beta_{4} \mathrm{X}_{4}+\beta_{5} \mathrm{X}_{5}+\mathrm{e}
$$

Keterangan :

$$
\begin{array}{ll}
\mathrm{Y} & =\text { Variabel terikat (Kinerja) } \\
\mathrm{a} & =\text { Nilai Konstanta } \\
\mathrm{X}_{1} & =\text { Variabel bebas (Transparansi) } \\
\mathrm{X}_{2} & =\text { Variabel bebas (Akuntabilitas) } \\
\mathrm{X}_{3} & =\text { Variabel bebas (Responsibilitas) } \\
\mathrm{X}_{4} & =\text { Variabel bebas (Independensi) } \\
\mathrm{X}_{5} & =\text { Variabel bebas (Kewajaran) } \\
\beta_{1} & =\text { Koefisien regresi dari Transparansi }\left(\mathrm{X}_{1}\right) \\
\beta_{2} & =\text { Koefisien regresi dari Akuntabilitas }\left(\mathrm{X}_{2}\right) \\
\beta_{3} & =\text { Koefisien regresi dari Responsibilitas }\left(\mathrm{X}_{3}\right) \\
\beta_{4} & =\text { Koefisien regresi dari Independensi }\left(\mathrm{X}_{4}\right) \\
\beta_{5} & =\text { Koefisien regresi dari Kewajaran }\left(\mathrm{X}_{5}\right) \\
\mathrm{e} & =\text { error (tingkat kesalahan pengganggu) }
\end{array}
$$

Berdasarkan hasil analisis yang dilakukan dapat diamati mengenai koefiein determinasi $\left(\mathrm{R}^{2}\right)$, Uji kelayakan model (uji F), dan uji hipotesis (uji t).

\section{HASIL DAN PEMBAHASAN}

Statistik deskriptif adalah statistik yang digunakan untuk menganalisa data dengan cara mendeskripsikan atau menggambarkan data yang telah terkumpul sebagaimana adanya tanpa bermaksud membuat kesimpulan yang berlaku untuk 
Ida Ayu Arina Mahadewi dan I G A. M. Asri Dwija Putri. Pengaruh ...

umum atau generalisasi. Hasil statistik deskriptif penelitian ini dapat dilihat pada Tabel 2 sebagai berikut:

Tabel 2.

Hasil Uji Statistik Deskriptif

\begin{tabular}{lrrrrrr}
\hline & Transparansi & Akuntabilitas & Responsibilitas & Independensi & Kewajaran & Kinerja \\
\hline N Valid & 120 & 120 & 120 & 120 & 120 & 120 \\
Mean & 12.743 & 11.844 & 14.905 & 14.277 & 13.929 & $4.142,7$ \\
Std. & 2.770 & 2.340 & 2.651 & 3.167 & 3.382 & 7.248 \\
Deviation & 7.676 & 5.476 & 7.030 & 10.034 & 11.440 & 52.536 \\
Variance & 4.796 & 7.854 & 6.659 & 5.785 & 6.998 & 25.765 \\
Minimum & 16.237 & 16.455 & 19.182 & 18.418 & 18.328 & 54.194 \\
Maximum & & & & & &
\end{tabular}

Variabel transparansi memiliki nilai minimum sebesar 4,796 dan nilai maksimum sebesar 16,237 dengan nilai rata-rata sebesar 12,743 . Nilai rata-rata sebesar 12,743 menunjukkan bahwa respon responden dalam menjawab pernyataan pada kuesioner cenderung merasa setuju pada masing-masing item pernyataan artinya kejelasan transparansi cenderung tinggi. Standar deviasi pada variabel transparansi adalah sebesar 2,770. Hal ini menunjukkan bahwa standar penyimpangan data terhadap nilai rata-ratanya adalah 2,770 .

Variabel akuntabilitas memiliki nilai minimum sebesar 7,854 dan nilai maksimum sebesar 16,455 dengan nilai rata-rata sebesar 11,844 . Nilai rata-rata sebesar 11,844 menunjukkan bahwa respon responden dalam menjawab pernyataan pada kuesioner cenderung merasa setuju pada masing-masing item pernyataan artinya akuntabilitas cenderung tinggi. Standar deviasi pada variabel akuntabilitas adalah sebesar 2,340. Hal ini menunjukkan bahwa standar penyimpangan data terhadap nilai rata-ratanya adalah 2,340. 
Variabel responsibilitas memiliki nilai minimum sebesar 6,659 dan nilai maksimum sebesar 19,182 dengan nilai rata-rata sebesar 14,905. Nilai rata-rata sebesar 14,905 menunjukkan bahwa respon responden dalam menjawab pernyataan pada kuesioner cenderung merasa setuju pada masing-masing item pernyataan artinya responsibilitas cenderung tinggi. Standar deviasi pada variabel responsibilitas adalah sebesar 2,651. Hal ini menunjukkan bahwa standar penyimpangan data terhadap nilai rata-ratanya adalah 2,651.

Variabel independensi memiliki nilai minimum sebesar 5,785 dan nilai maksimum sebesar 18,418 dengan nilai rata-rata sebesar 14,277 . Nilai rata-rata sebesar 14,277 menunjukkan bahwa respon responden dalam menjawab pernyataan pada kuesioner cenderung merasa setuju pada masing-masing item pernyataan artinya independensi cenderung tinggi. Standar deviasi pada variabel independen adalah sebesar 3,167. Hal ini menunjukkan bahwa standar penyimpangan data terhadap nilai rata-ratanya adalah 3,167.

Variabel kewajaran dan kesetaraan memiliki nilai minimum sebesar 6,998 dan nilai maksimum sebesar 18,328 dengan nilai rata-rata sebesar 13,929. Nilai rata-rata sebesar 13,929 menunjukkan bahwa respon responden dalam menjawab pernyataan pada kuesioner cenderung merasa setuju pada masingmasing item pernyataan artinya kewajaran dan kesetaraan cenderung tinggi. Standar deviasi pada variabel kewajaran dan kesetaraan adalah sebesar 3,382. Hal ini menunjukkan bahwa standar penyimpangan data terhadap nilai rata-ratanya adalah 3,382. 
Ida Ayu Arina Mahadewi dan I G A. M. Asri Dwija Putri. Pengaruh ...

Variabel kinerja memiliki nilai minimum sebesar 25,765 dan nilai maksimum sebesar 54,194 dengan nilai rata-rata sebesar 41,468. Nilai rata-rata sebesar 41,468 menunjukkan bahwa respon responden dalam menjawab pernyataan pada kuesioner cenderung merasa setuju pada masing-masing item pernyataan artinya Kinerja cenderung tinggi. Standar deviasi pada variabel kinerja adalah sebesar 7,248. Hal ini menunjukkan bahwa standar penyimpangan data terhadap nilai rata-ratanya adalah 7,248.

Pengujian data dalam penelitian ini menggunakan teknik analisis regresi linier berganda. Analisis regresi linear berganda dilakukan untuk mengetahui penerapan prinsip-prinsip good corporate governance terhadap kinerja Rumah Sakit di Kota Denpasar dengan menggunakan variabel transparansi, akuntabilitas, responsibilitas, independen, serta kewajaran dan kesetaraan yang akan diuji dengan tingkat signifikansi $\alpha=5 \%$ atau 0,05 . Hasil uji regresi linear berganda dapat dilihat pada Tabel 3 berikut ini:

Tabel 3.

Hasil Regresi Linear Berganda

\begin{tabular}{|c|c|c|c|c|}
\hline & \multirow[b]{2}{*}{ Model } & \multicolumn{2}{|c|}{ Unstandardized Coefficients } & \multirow{2}{*}{$\begin{array}{c}\text { Standardized } \\
\text { Coefficients } \\
\text { Beta }\end{array}$} \\
\hline & & B & Std. Error & \\
\hline \multirow[t]{6}{*}{1} & (Constant) & 8.294 & 2.868 & \\
\hline & Transparansi & .446 & .212 & .171 \\
\hline & Akuntabilitas & 628 & .276 & .203 \\
\hline & Responsibilitas & .542 & .274 & .198 \\
\hline & Independensi & .491 & .186 & .215 \\
\hline & Kewajaran & .356 & .157 & .166 \\
\hline
\end{tabular}

Berdasarkan hasil analisis regresi linier berganda seperti yang disajikan pada Tabel 3, maka persamaan strukturalnya adalah sebagai berikut :

$$
Y=8,294+0,446 X_{1}+0,628 X_{2}+0,542 X_{3}+0,491 X_{4}+0,356 X_{5}+e
$$


Nilai konstanta sebesar 8,294 menunjukkan bahwa bila nilai kejelasan transparansi $\left(\mathrm{X}_{1}\right)$, akuntabilitas $\left(\mathrm{X}_{2}\right)$, responsibilitas $\left(\mathrm{X}_{3}\right)$, independensi $\left(\mathrm{X}_{4}\right)$, dan kewajaran $\left(\mathrm{X}_{5}\right)$ sama dengan nol, maka cenderung terdapat pengaruh pada kinerja (Y).

Nilai koefisien $\beta 1=0,446$ menunjukkan transparansi $\left(\mathrm{X}_{1}\right)$ bernilai positif, hal ini berarti transparansi mempunyai pengaruh positif terhadap kinerja, bila transparansi meningkat satu satuan akan cenderung meningkatkan kinerja dengan asumsi variabel lainnya sama dengan nol.

Nilai koefisien $\beta 2=0,628$ menunjukkan akuntabilitas $\left(\mathrm{X}_{2}\right)$ bernilai positif, hal ini berarti akuntabilitas mempunyai pengaruh positif terhadap kinerja, bila akuntabilitas meningkat satu satuan akan cenderung meningkatnya kinerja dengan asumsi variabel lainnya sama dengan nol.

Nilai koefisien $\beta 3=0,542$ menunjukkan responsibilitas $\left(\mathrm{X}_{3}\right)$ bernilai positif, hal ini berarti responsibilitas mempunyai pengaruh positif terhadap kinerja, bila responsibilitas meningkat satu satuan akan cenderung meningkatnya kinerja dengan asumsi variabel lainnya sama dengan nol.

Nilai koefisien $\beta 4=0,491$ menunjukkan independensi $\left(\mathrm{X}_{4}\right)$ bernilai positif, hal ini berarti independen mempunyai pengaruh positif terhadap kinerja, bila independen meningkat satu satuan akan cenderung meningkatnya kinerja dengan asumsi variabel lainnya sama dengan nol.

Nilai koefisien $\beta 5=0,356$ menunjukkan kewajaran $\left(\mathrm{X}_{5}\right)$ bernilai positif, hal ini berarti kewajaran mempunyai pengaruh positif terhadap kinerja, bila 
kewajaran meningkat satu satuan akan cenderung meningkatnya kinerja dengan asumsi variabel lainnya sama dengan nol.

Tabel 4.

Hasil Uji Koefisien Determinasi

\begin{tabular}{|c|c|c|c|c|c|}
\hline Model & $\mathrm{R}$ & R Square & Adjusted R Square & $\begin{array}{l}\text { Std. Error of the } \\
\text { Estimate }\end{array}$ & Durbin-Watson \\
\hline 1 & $.741^{\mathrm{a}}$ & .549 & .529 & 4.972650 & 1.445 \\
\hline
\end{tabular}

Sumber: Data diolah, 2018

Koefisien determinasi mengukur seberapa jauh kemapuan model dalam menerapkan variabel-variabel dependen. Pada penelitian ini, koefisien determinasi yang digunakan adalah nilai dari Adjusted $\mathrm{R}^{2}$ yaitu sebesar 0,549. Hal ini menunjukkan bahwa 54,9\% kinerja dapat dipengaruhi secara signifikan oleh variabel transparansi, akuntabilitas, responsibilitas, independensi, serta kewajaran sedangkan sisanya sebesar $45,1 \%$ dijelaskan oleh variabel lain dari luar model penelitian ini.

Tabel 5.

Hasil Uji Kelayakan Model

\begin{tabular}{|c|c|c|c|c|c|c|}
\hline \multicolumn{2}{|c|}{ Model } & Sum of Squares & $\mathrm{df}$ & Mean Square & $\mathrm{F}$ & Sig. \\
\hline \multirow[t]{3}{*}{1} & Regression & 3432.849 & 5 & 686.570 & 27.766 & $.000^{\mathrm{a}}$ \\
\hline & Residual & 2818.906 & 114 & 24.727 & & \\
\hline & Total & 6251.756 & 119 & & & \\
\hline
\end{tabular}
Sumber: Data diolah, 2018

Uji F pada dasarnya menunjukkan apakah semua variabel bebas yang dimasukkan dalam model mempunyai pengaruh secara bersama-sama pada variabel dependen. Berdasarkan hasil perhitungan uji $F$ pada Tabel 4.11 menunjukkan bahwa nilai $\mathrm{F}_{\text {hitung }}$ sebesar 27,766 dengan nilai signifikansi $\mathrm{F}$ atau $p$ value sebesar 0,000 yang lebih kecil dari nilai $\alpha=0,05$. Artinya variabel transparansi, akuntabilitas, responsibilitas, independensi, serta kewajaran secara bersama-sama (simultan) berpengaruh pada kinerja. 
Tabel 6.

Hasil Uji Hipotesis

\begin{tabular}{ccccccc}
\hline & \multicolumn{5}{c}{$\begin{array}{c}\text { Unstandardized } \\
\text { Coefficients }\end{array}$} & $\begin{array}{c}\text { Standardized } \\
\text { Coefficients }\end{array}$ \\
& Model & $\mathrm{B}$ & Std. Error & Beta & $\mathrm{t}$ & Sig. \\
\hline 1 & (Constant) & 8.294 & 2.868 & & 2.892 & .005 \\
& Transparansi & .446 & .212 & .171 & 2.104 & .038 \\
& Akuntabilitas & .628 & .276 & .203 & 2.273 & .025 \\
& Responsibilitas & .542 & .274 & .198 & 1.980 & .050 \\
& Independensi & .491 & .186 & .215 & 2.634 & .010 \\
& Kewajaran & .356 & .157 & .166 & 2.268 & .025 \\
\hline Sumber:
\end{tabular}

Sumber: Data diolah, 2018

Pada Tabel 6 dapat dilihat bahwa variabel transparansi memiliki nilai $\mathrm{t}$ hitung sebesar 2,104 dengan tingkat signifikansi sebesar 0,038 lebih kecil dari dari nilai $\alpha=0,05$. Hal ini menunjukkan bahwa $\mathrm{H}_{0}$ ditolak dan $\mathrm{H}_{1}$ diterima, yang berarti bahwa Transparansi berpengaruh Positif terhadap Kinerja pada Rumah Sakit di Kota Denpasar.

Pada Tabel 6 dapat dilihat bahwa variabel akuntabilitas memiliki nilai t hitung sebesar 2,273 dengan tingkat signifikansi sebesar 0,025 lebih kecil dari dari nilai $\alpha=0,05$. Hal ini menunjukkan $\mathrm{H}_{0}$ ditolak dan $\mathrm{H}_{2}$ diterima, yang berarti bahwa Akuntabilitas berpengaruh Positif terhadap Kinerja pada Rumah Sakit di Kota Denpasar.

Pada Tabel 6 dapat dilihat bahwa variabel responsibilitas memiliki nilai $\mathrm{t}$ hitung sebesar 1,980 dengan tingkat signifikansi sebesar 0,050 lebih kecil dari dari nilai $\alpha=0,05$. Hal ini menunjukkan $\mathrm{H}_{0}$ ditolak dan $\mathrm{H}_{3}$ diterima, yang berarti bahwa Responsibilitas berpengaruh Positif terhadap Kinerja pada Rumah Sakit di Kota Denpasar.

Pada Tabel 6 dapat dilihat bahwa variabel independensi memiliki nilai $\mathrm{t}$ hitung sebesar 2,634 dengan tingkat signifikansi sebesar 0,010 lebih kecil dari 
dari nilai $\alpha=0,05$. Hal ini menunjukkan $\mathrm{H}_{0}$ ditolak dan $\mathrm{H}_{4}$ diterima, yang berarti bahwa Independensi berpengaruh Positif terhadap Kinerja pada Rumah Sakit di Kota Denpasar.

Pada Tabel 6 dapat dilihat bahwa variabel kewajaran memiliki nilai t hitung sebesar 2,268 dengan tingkat signifikansi sebesar 0,025 lebih besar dari dari nilai $\alpha=0,05$. Hal ini menunjukkan $\mathrm{H}_{0}$ ditolak dan $\mathrm{H}_{5}$ diterima, yang berarti bahwa Kewajaran berpengaruh Positif terhadap Kinerja pada Rumah Sakit di Kota Denpasar.

Berdasarkan hasil perhitungan yang ditunjukkan pada Tabel 6 bahwa variabel Transparansi berpengaruh Positif terhadap Kinerja pada Rumah Sakit di Kota Denpasar. Hal ini ditunjukkan dengan Nilai Beta sebesar 0,171 dan nilai signifikansi sebesar 0,038 yang lebih kecil dari tingkat signifikasi yang ditetapkan $(\alpha=0,05)$ sehingga hipotesis pertama $\left(\mathrm{H}_{1}\right)$ diterima yakni prinsip Transparansi berpengaruh Positif dan signifikan terhadap Kinerja yang terjadi pada Rumah Sakit di Kota Denpasar. Hal ini menunjukan bahwa pengungkapan ini informasi secara tepat waktu dan akurat dalam perusahaan akan meningkatkan kepercayaan stakeholders, sehingga kinerja perusahaan akan menjadi lebih baik.

Berdasarkan hasil perhitungan yang ditunjukkan pada Tabel 6 bahwa variabel Akuntabilitas berpengaruh Positif terhadap Kinerja pada Rumah Sakit di Kota Denpasar. Hal ini ditunjukkan dengan Nilai Beta sebesar 0,203 dan nilai signifikansi sebesar 0,025 yang lebih kecil dari tingkat signifikasi yang ditetapkan $(\alpha=0,05)$ sehingga hipotesis kedua $\left(\mathrm{H}_{2}\right)$ diterima yakni prinsip Akuntabilitas berpengaruh Positif dan signifikan terhadap Kinerja yang terjadi pada Rumah 
Sakit di Kota Denpasar. Kejelasan fungsi dan pertanggungjawaban dalam organisasi, maka semakin efektif pengelolaan perusahaan sehingga kinerja perusahaan akan meningkat.

Berdasarkan hasil perhitungan yang ditunjukkan pada Tabel 6 bahwa variabel Responsibilitas berpengaruh Positif terhadap Kinerja pada Rumah Sakit di Kota Denpasar. Hal ini ditunjukkan dengan Nilai Beta sebesar 0,198 dan nilai signifikansi sebesar 0,050 yang lebih kecil dari tingkat signifikasi yang ditetapkan $(\alpha=0,05)$ sehingga hipotesis ketiga $\left(\mathrm{H}_{3}\right)$ diterima yakni prinsip Responsibilitas berpengaruh Positif dan signifikan terhadap Kinerja yang terjadi pada Rumah Sakit di Kota Denpasar. Hal ini menunjukan bahwa kepatuhan perusahaan terhadap hukum dan bertanggungjawab terhadap masyarakat serta lingkungan perusahaan terhadap stakeholders, akan meningkatkan kinerja perusahaan.

Berdasarkan hasil perhitungan yang ditunjukkan pada Tabel 6 bahwa variabel Independensi berpengaruh Positif terhadap Kinerja pada Rumah Sakit di Kota Denpasar. Hal ini ditunjukkan dengan Nilai Beta sebesar 0,215 dan nilai signifikansi sebesar 0,010 yang lebih kecil dari tingkat signifikasi yang ditetapkan $(\alpha=0,05)$ sehingga hipotesis keempat $\left(\mathrm{H}_{4}\right)$ diterima yakni prinsip Independensi berpengaruh Positif dan signifikan terhadap Kinerja yang terjadi pada Rumah Sakit di Kota Denpasar. Semakin independen perusahaan dalam mengelola perusahaan akan mampu meningkatkan kinerjanya ke arah yang lebih baik.

Berdasarkan hasil perhitungan yang ditunjukkan pada Tabel 6 bahwa variabel Kewajaran berpengaruh Positif terhadap Kinerja pada Rumah Sakit di Kota Denpasar. Hal ini ditunjukkan dengan Nilai Beta sebesar 0,166 dan nilai 
signifikansi sebesar 0,025 yang lebih kecil dari tingkat signifikasi yang ditetapkan $(\alpha=0,05)$ sehingga hipotesis kelima $\left(\mathrm{H}_{5}\right)$ diterima yakni prinsip Kewajaran berpengaruh Positif dan signifikan terhadap Kinerja yang terjadi pada Rumah Sakit di Kota Denpasar. Hal ini menunjukan bahwa jika dalam mengelola usahanya perusahaan selalu berlandaskan kewajaran dan kesetaraan, maka kinerja perusahaan juga akan meningkat.

Berdasarkan pembahasan hasil penelitian dan dengan dilakukan pengujian hipotesis maka dapat dikatakan bahwa secara keseluruhan prinsip-prinsip good governance berpengaruh positif terhadap kinerja pada Rumah Sakit di Kota Denpasar. Hal ini terjadi karena prinsip-prinsip good governance membantu pengelola Rumah Sakit untuk mengatur bagaimana perusahaan dioperasikan dan dijalankan dengan baik.

Prinsip-prinsip Good Governance adalah sebagai sarana interaksi yang mengatur antar struktur dan mekanisme yang menjamin adanya kontrol, namun tetap mendorong efisiensi dan kinerja pada Rumah Sakit. Prinsip-prinsip Good Governance ini juga dapat dapat meningkatkan nilai dari Rumah Sakit dengan cara meningkatkan kinerja Rumah Sakit dari empat aspek ukuran kinerja yang meliputi aspek perspektif belajar dan tumbuh, perspektif proses internal bisnis, perspektif pelanggan, dan perspektif keuangan.

Penerapan prinsip-prinsip Good Governance yang dilakukan secara baik dan konsisten akan membuat segala kegiatan Rumah Sakit akan berjalan efektif dan efisien, hal ini disebabkan oleh prinsip-prinsip Good Governance bertujuan untuk melindungi setiap kepentingan stakeholders sehingga akan menimbulkan 
keadaan yang selaras di lingkungan Rumah Sakit. Keselarasan di lingkungan Rumah Sakit akan menjadi motivasi dan modal penting bagi Rumah Sakit melakukan aktivitasnya untuk mencapai tujuannya.

Hasil penelitian ini diharapkan dapat memberikan tambahan informasi mengenai penerapan prinsip-prinsip Good Corporate Governance terhadap kinerja yang terdiri dari transparansi, akuntabilitas, responsibilitas, independensi, serta kewajaran dan kesetaraan. Selain itu hasil penelitian ini mengkonfirmasi bahwa variabel transparansi, akuntabilitas, responsibilitas, independensi, serta kewajaran dan kesetaraan dapat mempengaruhi kinerja. Terdapat bukti empiris bagi peneliti dalam penerapan prinsip-prinsip Good Corporate Governance terhadap kinerja.

Hasil penelitian ini diharapkan mampu memberikan referensi, masukan dan tambahan informasi bagi pihak-pihak yang terkait dalam penerapan prinsipprinsip Good Governance terhadap kinerja pada Rumah Sakit di Kota Denpasar dalam mengambil keputusan dan menentukan kebijakan di masa yang akan datang terkait penerapan prinsip-prinsip Good Governance sehingga nantinya dapat meningkatkan kinerja organisasi.

\section{SIMPULAN}

Transparansi berpengaruh positif terhadap kinerja pada rumah sakit di Kota Denpasar. Hal ini menunjukan bahwa pengungkapan informasi secara tepat waktu dan akurat dalam perusahaan akan meningkatkan kepercayaan stakeholders, sehingga kinerja perusahaan akan menjadi lebih baik. 
Ida Ayu Arina Mahadewi dan I G A. M. Asri Dwija Putri. Pengaruh ...

Akuntabilitas berpengaruh positif terhadap kinerja pada rumah sakit di Kota Denpasar. Kejelasan fungsi dan pertanggungjawaban dalam organisasi, maka semakin efektif pengelolaan perusahaan, sehingga kinerja perusahaan akan meningkat.

Responsibilitas berpengaruh positif terhadap kinerja pada rumah sakit di Kota Denpasar. Hal ini menunjukan bahwa kepatuhan perusahaan terhadap hukum dan bertanggungjawab terhadap stakeholders akan meningkatkan kinerja perusahaan.

Independensi berpengaruh positif terhadap kinerja pada rumah sakit di Kota Denpasar. Semakin independen perusahaan dalam mengelola perusahaan, maka perusahaan akan terbebas dari kepentingan berbagai pihak yang merugikan, sehingga perusahaan akan mampu meningkatkan kinerjanya ke arah yang lebih baik.

Kewajaran berpengaruh positif terhadap kinerja pada rumah sakit di Kota Denpasar. Hal ini menunjukan bahwa jika dalam mengelola usahanya perusahaan selalu berlandaskan kewajaran dan kesetaraan, maka kinerja perusahaan juga akan meningkat.

Bagi Rumah Sakit, berdasarkan hasil yang diperoleh pada hasil uji statistik deskriptif variabel independensi menunjukan nilai terendah, sehingga peneliti menyarankan lebih meningkatkan nilai independensi dengan menempatkan peran dan tanggung jawab komisaris dan manajemen. Selain itu juga penelitian ini diharapkan dapat digunakan sebagai bahan pertimbangan oleh pengurus Rumah Sakit agar dalam mengelola organisasi Rumah Sakit menggunakan prinsip- 
prinsip good governance sebagai pedoman agar dapat meningkatkan kinerja Rumah Sakit.

Bagi Penelitian Selanjutnya dapat menambahkan responden dalam penelitian untuk lebih menjamin keakuratan data yang diberikan. Selain itu dapat memperluas objek penelitian dengan menggunakan Rumah Sakit di daerah yang berbeda yang berada di Provinsi Bali untuk melengkapi penelitian Rumah Sakit di seluruh Provinsi Bali.

Untuk peneliti selanjutnya juga dapat menggunakan objek lain seperti BPR atau LPD atau lembaga lainnya, diharapkan mengukur dengan menggunakan variabel lain dan menmbahkan variabel moderasi yang berpengaruh terhadap kinerja sehingga penelitian tersebut dapat lebih bermanfaat bagi instansi yang menjadi objek penelitian sehingga objek penelitian tersebut dapat meningkatkan penerapan prinsip-prinsip Good Coporate Governance secara signifikan.

\section{REFERENSI}

Anthony, 1 Robert N. \& Govindarajan, Vijay. (2005). Manajemen Control System. Jakarta: Salemba Empat.

Anton, FX. (2010). Menuju Teori Stewardship Manajemen. Majalah Ilmiah Informatika, 1(2).

Donaldson, L. \& Davis, J.H., (1991). Stewardship Theory on Agency Theory: CEO Governance and Shareholder Returns. Australian Journal of Management, 16,49.

Keputusan Menteri Kesehatan Republik Indonesia No.1204/Menkes/SK/X/2004 tentang Persyaratan Kesehatan Lingkungan Rumah Sakit.

Komite Nasional Kebijakan Governance (KNKG). (2006). Pedoman Umum Good Corporate Governance Indonesia. Jakarta. 
Mahaendrayasa, P. K. A., \& Putri, I. G. A. M. A. D. (2017). Pengaruh PrinsipPrinsip Good Corporate Governance Terhadap Kinerja Keuangan Lembaga Perkreditan Desa. E-Jurnal Akuntansi, 21, 970-995.

Permatasari, L. W., \& Gayatri. (2016). Profitabilitas Sebagai Pemoderasi Pengaruh Good Corporate Governance Pada Nilai Perusahaan. E-Jurnal Akuntansi, 3, 2307-2335.

Putri, Igam Asri Dwija. 2012. Pengaruh Kebijakan Dividen dan Good Corporate Governance Terhadap Manajemen Laba. Buletin Studi Ekonomi Vol.17 (2), $\mathrm{H}: 157-171$.

Putri, I. A. D. (2012). Peranan Good Corporate Governance Dan Budaya Terhadap Kinerja Organisasi. Jurnal Akuntansi \& Bisnis, 7(2), 193-204.

Putri, IGAM Asri Dwija \& Ulupui, I Gusti Ketut Agung. (2017). Pengantar Corporate Governance. Denpasar. CV Sastra Utama.

Putri, I Gst. Ag. Pramesti Dwi dan Wirasedana, I Wayan Pradnyatha. (2015). Analisis Perbandingan Penilaian Kinerja BPR Dengan Pendekatan Balanced Scorecard. E-Jurnal Akuntansi Universitas Udayana 13 (1), h:1-19.

Putri, I. G. A. M. A. D., Ulupui, I. G. K. A., \& Wirawati, N. G. P. (2017). Pengaruh Good Corporate Governance Dan Budaya Tri Hita Karana Pada Kinerja Bank Perkreditan Rakyat, 12(1), 17-24.

Peni, Emelia, Stanly D. Smith, \& Sami Vahamaa, (2013). Bank Corporate Governance and Real Estate Lending During the Financial Crisis. JRER, 35 (3).

Setyawan, K. M., \& Putri, I. G. A. M. A. D. (2013). Pengaruh Good Corporate Governance Terhadap Kinerja Keuangan Lembaga Pekreditan Desa Di Kecamatan Mengwi Kabupaten Badung, 3, 586-598.

Undang-Undang RI Nomor 44 tahun 2009 dan Peraturan Menteri Kesehatan Republik Indonesia No. 340/MENKES/PER/III/2010 tentang rumah sakit.

Wikrami, Ida Ayu Ganetri Priyadarshini \& Astika, Ida Bagus Putra. (2016). Pengaruh Manajemen Laba Pada Harga Eksekusi ESOP Dengan Good Corporate Governance Sebagai Variabel Pemoderasi. E-Jurnal Akuntansi Universitas Udayana 16 (1), h:416 - 443.

Wirawan, A. A. G. B. P., \& Putri, I. G. A. M. A. D. (2018). Pengaruh Penerapan Prinsip-Prinsip Gcg Dan Manajemen Risiko Pada Kinerja Keuangan Koperasi Di Kabupaten Gianyar, 23, 1791-1818. 